\title{
CASSAVA (MANIHOT ESCULENTA CRANTZ) IN THE AETIOLOGY OF KWASHIORKOR
}

\author{
BERYL P. KAMALU \\ Department of Veterinary Pathology and Microbiology, University of Nigeria, Nsukka, \\ Nigeria
}

\section{CONTENTS}

INTRODUCTION . . . . . . . . . . . . . . . . . . . . 121

THE DOG AS AN EXPERIMENTAL MODEL FOR KWASHIORKOR . . 123

DISTORTION OF PROTEIN AND AMINO ACID METABOLISM . . 125

DIGESTIBILITY OF CASSAVA AND ITS EFFECT ON GROWTH . . 128

SIGNIFICANCE OF THIOCYANATE . . . . . . . . . . . . . 128

IMPORTANCE OF POTASSIUM DEPLETION . . . . . . . . . 129

PATHOLOGICAL FEATURES OBSERVED . . . . . . . . . . 130

CEllular Oedema

KIDNEY FUNCTION . . . . . . . . . . . . . . . . . . 130

CIRCULATORY DISTURBANCFS . . . . . . . . . . . . . . . 130

HYPOINSULINAEMIA $. \quad . \quad . \quad . \quad . \quad . \quad$. . . . . . . . 131

PANCREATIC DYSFUNCTION AND ATROPHY . . . . . . . . . . . 131

MUSCLE WASTING . . . . . . . . . . . . . . . . . 132

HYPOTHESIS . . . . . . . . . . . . . . . . . . . . 132

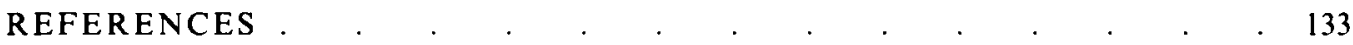

\section{INTRODUCTION}

The cassava root is an important dietary staple in virtually all tropical countries. Some time after 1504 cassava was taken by the Portuguese from tropical America to the Cape Verde Islands and from there to Africa and Asia (Moran, 1976). In both Africa and Latin America, cassava is the second or third most important dietary energy source (Phillips, 1983). It is a staple for more than 500 million people (Boccas, 1987). In times of famine, cassava is often the only food available (Cooke \& Cock, 1989).

Tissues of all cassava cultivars contain cyanogenic glucosides, although in varying concentrations. Researchers have failed to locate a cassava strain that is free from cyanogenic glucoside (Cooke \& Cock, 1989). Nartey (1968) showed that linamarin and lotaustralin (methyl-linamarin) constitute the cyanogenic material of cassava, Manihot esculenta Crantz, in the proportions of $93 \%$ and $7 \%$ respectively. Cyanogenic glucosides are compounds which undergo hydrolysis to produce hydrogen cyanide, which can cause acute poisoning. Traditionally, the cassava root with high cyanogenic content is processed to remove the cyanogenic glucosides and to convert it into a storable form such as gari. In West Africa women peel, wash and grate cassava tubers to prepare gari. They ferment the grated cassava in bags for a few days and then heat it in small quantities to drive off water and cyanide. In Brazil cassava is fermented to form farinha de manioca. In Asia cassava 
is processed to form cassava chips and tapioca. However, processing does not remove all the cyanogenic glucosides; some residual amounts are always found. In gari, concentrations of linamarin yielding about $2 \mathrm{mg} \mathrm{HCN} / 100 \mathrm{~g}$ may be found. Roots of cassava plants with low cyanogenic glucoside content are eaten after simple cooking such as boiling, frying or roasting. Cyanogenic glucoside, mainly linamarin, is therefore ingested whenever cassava foods are eaten.

It is the observation of the author that areas in which cassava is an important staple coincide with the areas in which kwashiorkor is common and also coincide with areas of poverty and intense human suffering. Cassava is grown and consumed in countries of Africa, Asia and Latin America (Table 1 and Fig. 1), where kwashiorkor is also common.

Very often the national data on human consumption of cassava are misleading because cassava may be the primary staple in certain areas but not in others. For example, cassava is more important in the south and east of Nigeria than in the north. In a survey of southern Nigeria, Nicol (1952) found that $25-56 \%$ of the dietary energy came from cassava, as opposed to the national figure of $14 \%$. Bailey's (1961) surveys in Java showed that $63.5 \%$ of the energy intake was from cassava as opposed to the Indonesian national figure of $15 \cdot 2 \%$.

Interest in the problem of childhood malnutrition by WHO and FAO led to a survey in Africa south of the Sahara by Brock \& Autret (1952). This survey was carried out mainly in rural Africa and the report concluded that, at that time, kwashiorkor was the most serious and widespread nutritional disorder known to medical and nutritional science. The subsequent joint WHO and FAO surveys of Autret \& Behar (1954) in Central America and Waterlow \& Vergara in Brazil (1957) established the essential identity of what was described as 'protein deficiency disease' as it occurred in Latin America. Hundreds of reports of severe malnutrition in children have since appeared from various countries, and it is clear that the syndrome is common to nearly all technically underdeveloped countries in the world (Viteri et al. 1964). Bailey (1961) reported that hunger oedema in adults was endemic in areas of Java where dried cassava was the dietary staple, and stated that the condition resembled the protein malnutrition seen in African adults. Bailey (1961) also stated that kwashiorkor in children in these areas was common.

Linamarin is also the cyanogenic glucoside found in linseed, which is an important cattle food, and in pulses, which are eaten by man. Among the pulses, Phaseolus lunatus, lima bean, contains the highest level of linamarin. The native American white variety of lima bean yields $10 \mathrm{mg} \mathrm{HCN} / 100 \mathrm{~g}$, which is less than that from varieties originating in Africa and the East. Concentrations of linamarin yielding $\sim 2 \mathrm{mg} \mathrm{HCN} / 100 \mathrm{~g}$ may be found in Phaseolus vulgaris (kidney, haricot or navy bean, red pea), Vigna sinensis (black-eye pea), and Pisum sativum (garden pea) (Montgomery, 1980). Furthermore, kwashiorkor may be found in countries other than those in which cassava is eaten; examples are North America (Rossouw, 1989), China, Hungary, Greece, Spain and Morocco (Viteri et al. 1964). These are areas in which pulses and other foods containing linamarin and other cyanogenic glucosides are consumed.

The purpose of this review is to examine the role of linamarin in the aetiology of kwashiorkor and to marshal evidence relating to the occurrence and distribution of kwashiorkor as it coincides with cassava consumption worldwide. Kwashiorkor is characterized by low serum albumin concentration, abnormal plasma amino acid pattern and ratios, oedema, potassium depletion, increase in subcutaneous fat with muscle wasting, low insulin levels, pancreatic dysfunction and atrophy and nephrosis. Cassava (gari) diets caused all these conditions. There is, therefore, a linkage and possibly a direct causative relationship between cassava consumption and kwashiorkor and that link, it is suggested, is intact linamarin. In most, if not all, the work reviewed, cassava is used as gari. 
Table 1. Major countries* in which kwashiorkor is found $\ddagger$ and cassava is eaten $\S \|$

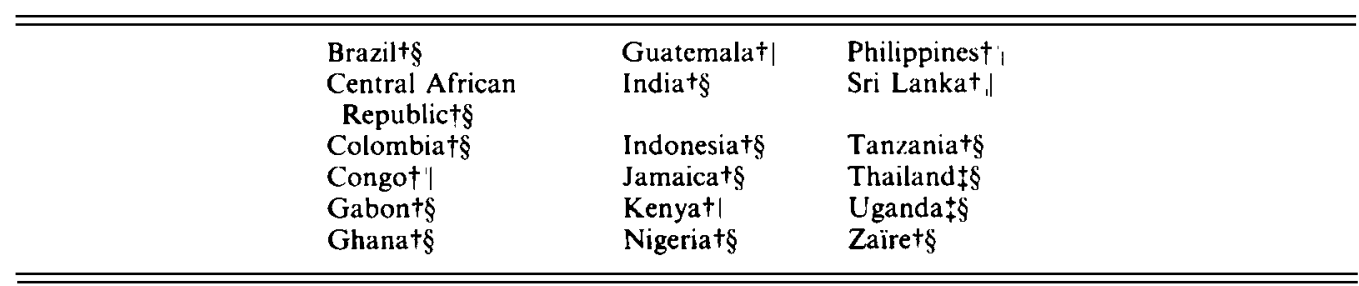

* This list is not exhaustive. Only countries with readily published information have been listed.

$\dagger$ Viteri et al. (1964).

+ Alleyne et al. (1977).

$\$$ Nestel (1973).

I Anon. (1987).

\section{THE DOG AS AN EXPERIMENTAL MODEL FOR KWASHIORKOR}

The dog has been used to develop this hypothesis, as there is extensive evidence of close similarities between kwashiorkor in man and the same condition in dogs. For instance, Giesecke (1985) has pointed out that only man, dog, cat and certain primates among monogastric mammals do not have more or less extended forestomach areas that permit microbial fermentation of ingested or infused nutrients, and that the length of the intestine is six times the body length in both man and dog. Barnard (1969) showed that the relative importance of microbial productivity in the foregut was associated with pancreatic ribonuclease (EC 3.1.27.5) activity, which is needed for the recycling of nucleic acid phosphate. The content of pancreatic ribonuclease $(\mu \mathrm{g} / \mathrm{g}$ pancreatic tissue) was 0.5 in dog and cat, 1.0 in man, 80.0 in pig and 260.0 in rat. These observations suggest similarity between the dog and man in anatomical features and fermentation activities in the gut.

The similarity between dog and man is further emphasized by similarities in metabolism. Phosphoenol pyruvate carboxykinase (EC 4.1.1.49), the key enzyme for the regulation of gluconeogenesis, which transforms mitochondrial oxaloacetate into phosphoenolpyruvate for further upgrading to glucose by cytosolic enzymes, is distributed in both cytosol and mitochondria of hepatocytes, but the compartmentation of the enzyme varies with species. The percentages of cytosolic and mitochondrial enzyme, respectively, are 35 and 65 in the $\mathrm{dog}, 40$ and 60 in man, 71 and 29 in pig and 90 and 10 in rat. In conditions of hunger or diabetes only the activity of cytosolic phosphoenolpyruvate carboxykinase is increased, not the mitochondrial enzyme (Hanson \& Garber, 1972; Soling \& Kleinicke, 1976). In species with high mitochondrial phosphoenolpyruvate carboxykinase activity a more steady supply of glucose is maintained by constant gluconeogenesis (Giesecke, 1985). In addition, Turner \& Bagnara (1971) reported that the metabolic defects occurring in depancreatized dogs are the same as those appearing in diabetic man.

Baker \& Speer (1983) observed that, regardless of age, dogs do very poorly on argininedeficient diets. Arginine is also considered a nutritionally essential amino acid for humans (Harper et al. 1979). Orotic aciduria develops in dogs fed on arginine-deficient diets (Baker \& Speer, 1983), and in humans deficient in ornithine carbamoyltransferase (EC 2.1.3.3), an enzyme concerned in arginine biosynthesis (Harper et al. 1979). This suggests that there is a close similarity in protein metabolism between man and dog.

In potassium depletion, structural alterations appear in the epithelium of the proximal convoluted tubule of the kidney in dogs (Kamalu, 1993) and man (Welt, 1970).

The foregoing examples of similarities between dog and man suggest that the dog is a 


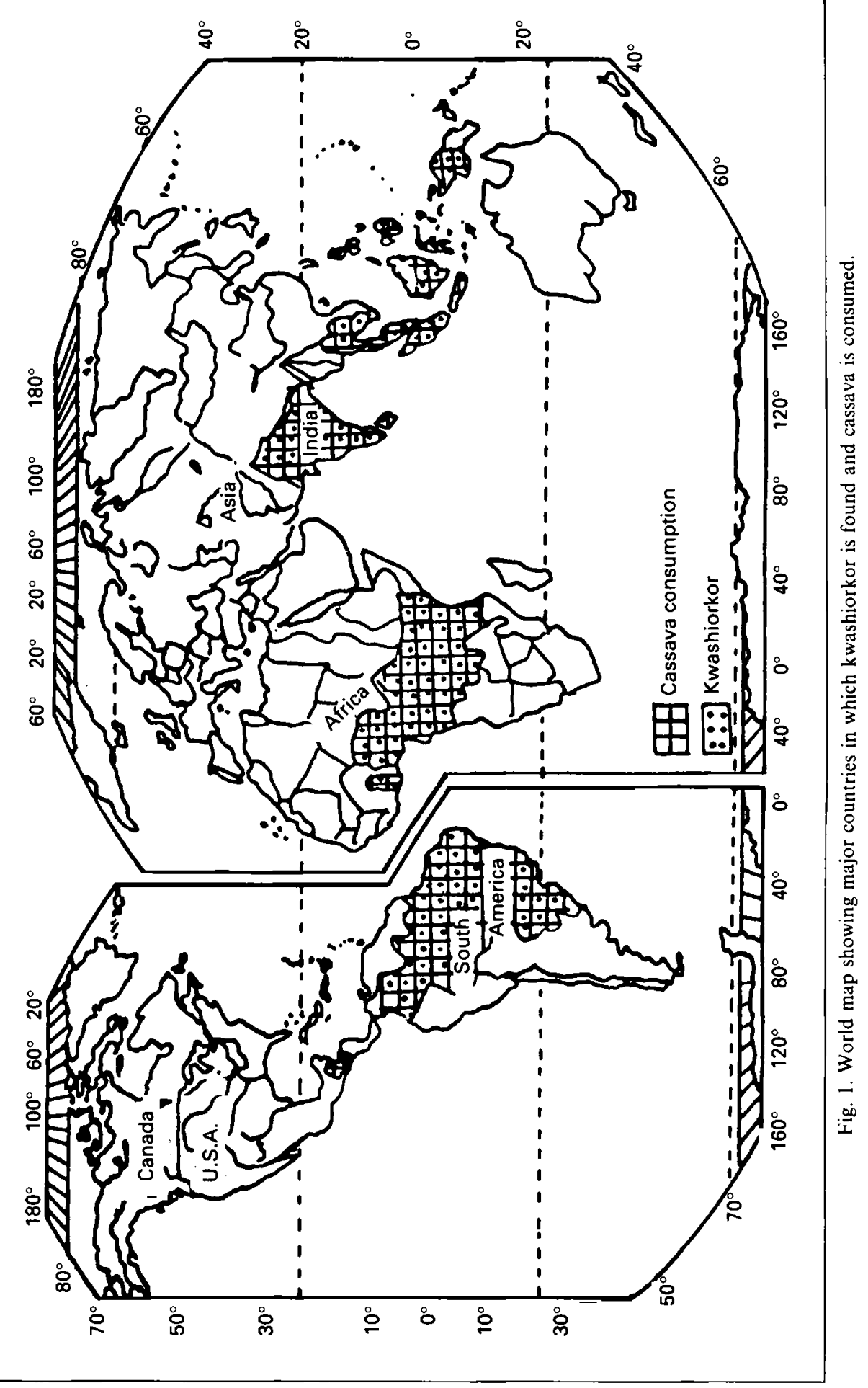


valid animal model for kwashiorkor as seen in individuals where cassava is the dietary staple.

\section{DISTORTION OF PROTEIN AND AMINO ACID METABOLISM}

Kamalu (1993) found that when growing dogs were fed on a diet consisting of $130 \mathrm{~g}$ crude protein $(\mathrm{N} \times 6.25) / \mathrm{kg}$ in the form of lean pork, a vitamin and mineral supplement, and gari as the carbohydrate source, which was expected to generate $1.08 \mathrm{mg} \mathrm{HCN} / 100 \mathrm{~g}$ food, for a period of 14 weeks, serum albumin concentration fell to a level lower than that of the control dogs, which were fed on a similar diet but with rice as the carbohydrate source. Similarly, a group of dogs fed on the control diet to which cyanide was added (rice $+\mathrm{NaCN}$ ) at the level of that found in the gari diet showed a serum albumin concentration significantly lower than that of the control dogs.

Detailed analysis of the plasma free amino acids revealed that there were severe distortions in the amino acid patterns and ratios in the gari-fed dogs as compared with the control dogs, but similar distortions were not observed in the dogs fed on rice + cyanide. Because these measurements were made on pooled samples, the statistical significance of the changes seen was not considered, but only the direction of the changes. Table 2 summarizes the effects of the diets on plasma free amino acid patterns and ratios. Plasma free concentrations of valine, threonine, alanine, tyrosine, lysine and arginine were decreased, and isoleucine and leucine showed a slight tendency towards decrease in the garifed dogs when compared to concentrations in the controls and the dogs fed on rice + cyanide. Plasma free concentrations of methionine, phenylalanine and aspartic acid were moderately elevated in the gari-fed dogs and markedly elevated in the dogs fed on rice + cyanide, and histidine was elevated in both groups when compared to the control dogs. The concentrations of glycine and serine were very markedly elevated in the gari-fed dogs but were little affected in the dogs fed on rice + cyanide as compared to the controls.

In the gari-fed dogs, the ratio (glycine + serine + glutamic acid): (leucine + isoleucine + valine) increased $400 \%$ above the value for the control dogs, whereas this ratio in the dogs fed on rice + cyanide was essentially the same as for the control dogs. The ratio (essential amino acids):(non-essential amino acids) in the gari-fed dogs showed a decrease of $57 \%$ when compared with the controls, whereas in the dogs fed on rice + cyanide it showed an increase of $23 \%$.

The distortions in the plasma amino acid patterns and ratios observed in the gari-fed dogs in this study, in which $130 \mathrm{~g}$ crude protein $(\mathrm{N} \times 6.25) / \mathrm{kg}$ was fed in the form of lean pork, resembled those found in experimental protein malnutrition in animals and kwashiorkor in children, even though amino acid supply was not a limiting factor. Lean pork is a good source of essential amino acids, and because gari is low in protein compared to rice $-1.6 \mathrm{~g} / 100 \mathrm{~g}$ in gari and $7.5 \mathrm{~g} / 100 \mathrm{~g}$ in rice $(\mathrm{FAO}, 1970)-60 \%$ more lean pork was added to the gari diet than to the rice diet, so that all the diets contained $130 \mathrm{~g}$ crude protein $(\mathrm{N} \times 6.25) / \mathrm{kg}$.

The similarity between the results of feeding gari with adequate protein and protein-energy malnutrition were demonstrated by the experiments of Grimble \& Whitehead (1969). These authors studied changes in the serum amino acid pattern during progressive primary protein malnutrition in young pigs on a diet of a cereal mixture of barley, maize and wheatings as the carbohydrate source. A high ratio of certain nonessential to essential amino acids in plasma was related to various abnormalities associated with malnutrition but, most important, the ratio started to become elevated only when the protein quality of the diet was made so poor that growth was seriously affected and serum 
Table 2. The effects of experimental diets on the concentrations of plasma free amino acids $(\mu \mathrm{mol} / \mathrm{ml})$ and on plasma free amino acid ratios in growing male dogs after 14 weeks on experimental diets

(Measurements were made on pooled plasma samples from six male dogs in each group)

\begin{tabular}{|c|c|c|c|c|c|}
\hline \multirow[b]{2}{*}{$\begin{array}{l}\text { Plasma free } \\
\text { amino acid }\end{array}$} & \multirow[b]{2}{*}{$\begin{array}{l}\text { Control } \\
\text { (rice) }\end{array}$} & \multicolumn{4}{|c|}{ Dietary group and change from control $(\%)$} \\
\hline & & $\begin{array}{c}\text { Cassava } \\
\text { (gari) }\end{array}$ & & $\begin{array}{l}\text { Rice + } \\
\text { cyanide }\end{array}$ & \\
\hline Aspartic acid & $20 \cdot 44$ & $32 \cdot 23$ & $57.68^{\star}$ & $43 \cdot 80$ & $114 \cdot 28^{\wedge}$ \\
\hline Threonine & $167 \cdot 84$ & $34 \cdot 34$ & $79 \cdot 5 ;$ & $172 \cdot 04$ & $2 \cdot 5$ \\
\hline Serine & $734 \cdot 6$ & $2364 \cdot 60$ & $221.88 \uparrow$ & $729 \cdot 69$ & $0.6 \downarrow$ \\
\hline Glutamic acid & 173.62 & $293 \cdot 81$ & $69 \cdot 22 \uparrow$ & 319.99 & $84 \cdot 30 \uparrow$ \\
\hline Proline & $232 \cdot 84$ & $196 \cdot 35$ & $15.67 !$ & $213 \cdot 73$ & $8.20 \downarrow$ \\
\hline Glycine & $336 \cdot 35$ & $1552 \cdot 33$ & $361 \cdot 52$ & $378 \cdot 16$ & $12.43 \uparrow$ \\
\hline Alanine & 1214.59 & 203.93 & $83 \cdot 20$ & 745.90 & $38.58 !$ \\
\hline Valine & $171 \cdot 81$ & $128 \cdot 18$ & 25.39 & 183.77 & $6.96 *$ \\
\hline Methionine & $17 \cdot 16$ & $22 \cdot 72$ & 32.40 & $37 \cdot 40$ & $117.94^{\wedge}$ \\
\hline Isoleucine & $55 \cdot 56$ & $55 \cdot 11$ & 0.80 & $67 \cdot 30$ & $21.13^{\wedge}$ \\
\hline Leucine & 101.98 & $97 \cdot 40$ & 4.49 & 135.58 & $32 \cdot 94$ * \\
\hline Tyrosine & $45 \cdot 20$ & $30 \cdot 68$ & $32 \cdot 12$ & 66.94 & 48.09 \\
\hline Phenylalanine & $33 \cdot 66$ & $46 \cdot 55$ & 38.29 & $70 \cdot 76$ & $110-21$ \\
\hline Lysine & 333.65 & $214 \cdot 16$ & 35.81 & $305 \cdot 20$ & 8.52 \\
\hline Histidine & $95 \cdot 30$ & 120.03 & $25.94 \uparrow$ & 106.06 & 11.291 \\
\hline 3-Methyl-histidine & $1631 \cdot 18$ & $1950 \cdot 58$ & $19 \cdot 58 \uparrow$ & $2336 \cdot 47$ & $43.23 \uparrow$ \\
\hline Arginine & $114 \cdot 35$ & 91.79 & $19 \cdot 72 \downarrow$ & 137.08 & $19.87 \uparrow$ \\
\hline $\begin{array}{l}\text { Ratio glycine }+ \text { serine }+ \\
\text { glutamic acid : leucine }+ \\
\text { isoleucine }+ \text { valine }\end{array}$ & $3 \cdot 78$ & $15 \cdot 00$ & $396.82 \uparrow$ & 3.69 & $1.43 \downarrow$ \\
\hline $\begin{array}{l}\text { Ratio essential amino } \\
\text { acids: non-essential } \\
\text { amino acids }\end{array}$ & 0.288 & $0 \cdot 123$ & 57.40 & $0 \cdot 355$ & $23 \cdot 12$ * \\
\hline
\end{tabular}

$\uparrow$ Percentage increase, $\downarrow$ percentage decrease.

albumin concentration began to fall. Detailed analysis of serum amino acid concentrations at this stage (Grimble \& Whitehead, 1970a) showed that the concentrations of valine, leucine, isoleucine, threonine and tyrosine fell. Grimble \& Whitehead $(1970 a)$ called the changes that occurred when growth was affected and serum albumin concentration fell 'Phase B' of the amino acid pattern. Phase C occurred when energy intake had fallen due to anorexia. Here the concentration of alanine fell significantly below control levels. Phase A of the amino acid pattern occurred when energy intake was normal and protein intake, though reduced, was still adequate for a good rate of growth, and the serum amino acid concentrations were the same as the control.

Grimble \& Whitehead $(1970 \mathrm{~b})$ studied fasting serum amino acid patterns in untreated kwashiorkor in children, and changes in serum amino acid patterns in the same children fed different levels of protein, with steamed plantain as the carbohydrate source after recovery from kwashiorkor. The amino acid patterns were similar to those described for malnourished pigs. When the protein content of the diet was reduced to levels inadequate to support the needs imposed by a rapid rate of catch-up growth, Phase B, the concentrations of branched-chain amino acids and threonine fell, but that of glycine became elevated. Grimble \& Whitehead $(1970 \mathrm{~b})$ found that the plasma concentration of valine started to fall first among the branched-chain amino acids, at which time the plasma 
concentration of glycine started to rise and serum albumin level to fall. In untreated kwashiorkor, Phase $\mathrm{C}$, the concentrations of the branched-chain amino acids and threonine were further depressed compared with Phase B, and alanine, methionine, tyrosine, serine and lysine were also significantly lower.

The fall in the plasma concentrations of valine and threonine and the very marked elevation of glycine in the gari-fed dogs resembles Phase B of protein malnutrition in Grimble \& Whitehead's children and pigs, while the fall in the concentration of tyrosine in the dogs was similar to Phase $\mathrm{B}$ in the pigs. The fall in the concentration of alanine and lysine in the gari-fed dogs resembled the findings in Phase $\mathrm{C}$ or untreated kwashiorkor in children and pigs, although lysine did not fall in pigs.

Grimble \& Whitehead $(1970 \mathrm{~b})$ stated that low levels of serum alanine have been a consistent finding in severe kwashiorkor in different parts of the world, and concluded that total energy deprivation as a result of anorexia is an eventual feature of severe kwashiorkor in most countries. Felig et al. (1969) showed that the initial reduction in alanine is caused by raised and preferential liver utilization of the amino acid during early starvation. Alanine is a key amino acid in gluconeogenesis and serves as a direct source of glucose for brain metabolism until the latter organ adapts to keto acid utilization (Owen et al. 1967).

In the gari-fed dogs the concentration of methionine was greater than in the controls. This is similar to the finding of normal serum methionine levels, but low levels of the branched-chain amino acids and serum albumin were found by Delange et al. (1983) among the population in Kivu, Zaire, where there was a marked increase in cassava consumption and severe protein-energy malnutrition. It is also similar to the finding by Chin et al. (1992) of raised serum methionine in all individuals in a study to evaluate malnutrition in chronic liver disease. Methionine is a sulphur-containing amino acid which is thought to be involved in the detoxification of any $\mathrm{HCN}$ produced as a result of hydrolysis of linamarin. The high or normal levels of serum methionine in the presence of protein-energy malnutrition with cassava diets may be due to abnormal methionine metabolism induced by the activity of some factor in cassava on the liver, or may be due to the accumulation of methionine released as a result of the breakdown of muscle protein for gluconeogenesis. Gluconeogenesis from protein is high when cassava is consumed (Kamalu, 1991a).

Grimble \& Whitehead (1969) stated that in Uganda the amino acid ratios in severe kwashiorkor are as much as $400-800 \%$ higher than those found in healthy children, and they found that the amino acid ratio rises fairly quickly when a child or animal is fed on a low-protein high-calorie diet, but only if the diet is so poor that it has some detrimental effect on the body. In the group of dogs fed on the gari diet, the amino acid ratio rose to $400 \%$ higher than that found in the control group of dogs after 14 weeks on the diet. This is similar to the findings in children with kwashiorkor.

One is startled by the finding that a cassava-based diet containing $130 \mathrm{~g}$ crude protein $(\mathrm{N} \times 6.25) / \mathrm{kg}$ in the form of lean pork and supplemented with minerals and vitamins, fed to growing dogs for 14 weeks, should produce a condition allied to kwashiorkor. There is consequently a great need to examine the significance of this abnormality, because of the importance of cassava as a dietary staple for millions of people in areas where kwashiorkor is common.

Some of the biochemical features of kwashiorkor, notably the low serum albumin and altered amino acid pattern, do suggest a state of protein depletion. However, our understanding of the pathogenesis of the major feature of kwashiorkor, oedema, is still incomplete. Animal experiments with diets high in carbohydrate and low in protein do not fully explain kwashiorkor. Grimble \& Whitehead (1970 b) found that in pigs, biochemical changes typical of kwashiorkor did not appear until the appetite of the animals had fallen so that their food intake was reduced. 


\section{DIGESTIBILITY OF CASSAVA AND ITS EFFECT ON GROWTH}

In order to interpret the author's findings, we should first look at the apparent digestibilities of the diets fed to the dogs. The constituents of a diet are available only if digestive and absorptive functions are not impaired. Kamalu $(1991 \mathrm{~b})$ found that after a period of 8 weeks on the experimental diets, the apparent digestibilities of rice and gari starch were the same in the dog, but that rice fibre was more digestible than gari fibre. Nicol \& Phillips (1978) found that the apparent digestibilities of rice and gari were the same when fed to young Nigerian men. Hamaker et al. (1991) found that all the cassava fibre fed in diets given to preschool children in Peru was recovered in the faeces. Consequently, there is no difference in the apparent digestibility of gari in dogs and man.

Kamalu (1991 $b$ ) also found that there was no significant difference in growth, measured as mean weekly percentage change in weight, between the rice-fed dogs (controls) and the gari-fed dogs during the 14-week experimental period. However, the mean weekly percentage change in weight in the dogs fed on rice + cyanide was significantly depressed as early as week 1 of the experiment, and the growth-retarding effect continued until the end of the experiment. Regression analysis showed that growth was linear for all groups. The study showed that although the addition of cyanide to rice depressed growth, the cyanogenic glucoside of gari appeared to have no effect on growth. This is in agreement with the findings of Gomez et al. (1987) in broilers, Radwan et al. (1989) in rabbits and Zinn \& De Peters (1992) in feed-lot cattle.

Koskelo et al. (1990) found that because muscle wasting was accompanied by simultaneous increase of adipose tissue, relative body weight did not decrease in children with newly diagnosed acute leukaemia, and therefore did not reveal the nutritional protein depletion that existed. This resembles the finding in the gari-fed dogs that mean weekly percentage change in weight did not differ from that of the rice-fed dogs, even though the serum albumin concentration was significantly lower.

Determination of bone growth by measurement of the closure of the proximal epiphysis of the ulna showed that the rates of bone growth in the rice-fed and the gari-fed dogs were the same during the 14-week experimental period, whereas bone growth in the dogs fed on rice + cyanide was significantly inhibited; this inhibitory effect was apparent by the end of the first week of the experiment and continued for the duration of the experimental period. The cyanogenic glucosides of gari therefore exerted no inhibitory effect on bone growth. This was emphasized by the finding that alkaline phosphatase (EC 3.1.3.1) activity at week 14 was significantly lower in the dogs fed on rice + cyanide than in the gari-fed dogs, indicating the difference in osteoblastic activity in growth and calcification of the bones of the dogs in the two groups. The effect of kwashiorkor on skeletal growth is mild.

\section{SIGNIFICANCE OF THIOCYANATE}

It is a well-established fact that the ingestion of sublethal levels of cyanogenic compounds in foods results in the rise of serum thiocyanate (Montgomery, 1980). Cyanide reacts with thiosulphate in the presence of the enzyme rhodanese (thiosulphate sulphurtransferase; $E C 2.8 .1 .1)$ to form thiocyanate and sulphite. A great elevation of rhodanese activity in rabbits treated with either linamarin or cyanide indicated an attempt to detoxify cyanide to thiocyanate (Padmaja \& Panikkar (1989); serum rhodanese activity was high in cassava-consuming patients with chronic pancreatitis (Narendranathan et al. 1989); and very high serum levels of thiocyanate were found among people in the Tarime district in northern Tanzania whose diet consisted almost entirely of cassava (Howlett et al. 1990). Thiocyanate is a well-recognized goitrogen, which functions by inhibiting the trapping of 
iodine by the thyroid gland, thereby depressing thyroid hormone synthesis and thyroid function.

Kamalu \& Agharanya (1991) found that although the feeding of the gari diet led to a rise in plasma thiocyanate, the level was much lower than that produced by the rice + cyanide diet, even though the two diets were designed to generate the same amount of HCN. It is possible that the cyanogenic glucoside fed in the gari diet was not being completely metabolized to HCN by the dogs. Barrett et al. (1977) and Maduagwu (1989) showed that some of the linamarin orally administered to rats is absorbed intact and excreted in the urine. Excretion of intact linamarin could have been responsible for the differences in the levels of plasma thiocyanate observed in the two groups of dogs.

Kamalu \& Agharanya (1991) also found that the total serum triiodothyronine $\left(T_{3}\right)$ concentration, the weight of the thyroid gland and the histology of the thyroid gland in the gari-fed dogs were not different from those of the rice (control)-fed dogs. However, the total serum $T_{3}$ concentration was significantly lower, and the weight of the thyroid gland was significantly greater in the dogs fed on rice + cyanide than in those fed on rice or gari. The histological picture showed that the increase in the size of the thyroid gland in the dogs fed on rice + cyanide was due to changes consistent with parenchymatous goitre. These changes confirmed the goitrogenic action of the high levels of plasma thiocyanate found, in agreement with previous observations. Sihombing et al. (1971) showed that administration of thiocyanate to pigs produced thyroid enlargement.

Growth is influenced by $T_{3}$ and is not depressed until total serum $T_{3}$ declines (Barry et al. 1983). The significant depression in growth rate of the dogs fed on rice + cyanide compared to those on gari was evidently due to the low total serum $T_{3}$ produced in this group of dogs as a result of the goitrogenic action of thiocyanate.

\section{IMPORTANCE OF POTASSIUM DEPLETION}

Reduced total body potassium is a common feature in all malnourished children (Millward, 1979; Tolboom et al. 1986). Low potassium levels in cardiac muscle have previously been associated with linamarin and cyanide ingestion. Philbrick et al. (1977) reported that blood taken just before death from rats dosed with a lethal amount of linamarin $(500 \mathrm{mg} / \mathrm{kg})$ or $\mathrm{KCN}(6 \mathrm{mg} / \mathrm{kg})$ had increased serum potassium. Potassium concentrations in the cardiac tissue of these rats were decreased, indicating that linamarin and cyanide had similar effects and suggesting that cyanide, released during digestion or following absorption of linamarin, was a major factor in the toxicity of the glucoside. This conclusion was supported by the increased lactate:pyruvate ratios and the decreased cardiac cytochrome oxidase (EC 1.9.3.1) activities caused by both linamarin and cyanide. Nevertheless, despite these similarities it was felt that the metabolic effects from linamarin ingestion might not be caused entirely by the release of cyanide. Hill (1977) reported that, in general, adenosinetriphosphatase (ATPase, EC 3.6.1.3) activities were significantly reduced by linamarin, indicating an interference with the release of energy, and that at the sublethal dose of $25 \mathrm{mg} / 100 \mathrm{~g}$ body weight, cardiac $\mathrm{Na}^{+}-\mathrm{K}^{+}$-ATPase was affected. It was of considerable interest that the activity of $\mathrm{Na}^{+}-\mathrm{K}^{+}$-ATPase in the heart is specifically reduced by the glucosides ouabain (Glynn, 1964) and digitalis (Matsui \& Schwartz, 1967), raising the possibility that linamarin may exert a toxic effect partly by a mechanism independent of HCN. One of the earliest and most important effects of reduced ATP activity is acute cellular swelling (cellular oedema) (Robbins \& Cotran, 1979).

Kamalu (1993) reported that plasma potassium and plasma calcium concentrations in gari-fed dogs were significantly decreased after a period of 14 weeks on the diet, and that the plasma concentration of potassium in the dogs fed on rice + cyanide was decreased but not 
significantly so even though, based on the amount of plasma thiocyanate formed, the gari diet appeared to generate significantly less cyanide than the rice + cyanide diet in dogs. Serum potassium concentrations are generally low in potassium depletion. In humans, a total intracellular potassium loss of about $100-200 \mathrm{mmol}$ is required before serum potassium concentration falls below normal (Tietz \& Siggaard-Anderson, 1982). These data explain the hypothesis that linamarin may exert a toxic effect partly by a mechanism independent of $\mathrm{HCN}$, i.e. by reducing the activity of $\mathrm{Na}^{+}-\mathrm{K}^{+}-\mathrm{ATPa}$. In other words, linamarin in gari caused a feature in the dog that is characteristic of kwashiorkor, namely potassium depletion, despite an adequate supply of good quality protein.

In potassium depletion, cells show degenerative changes in the form of swelling and vacuolation (cellular oedema) attributed to deranged membrane permeability induced by electrolyte imbalance.

\section{PATHOLOGICAL FEATURES OBSERVED}

\section{CELLULAR OEDEMA}

Ononogbu \& Emole (1978) fed a gari diet containing $12 \%$ protein on a dry matter basis to rats for 4 weeks. Microscopic examination revealed vacuolation of the liver. In her experiment on dogs fed gari with $130 \mathrm{~g}$ crude protein $(\mathrm{N} \times 6.25) / \mathrm{kg})$, Kamalu (1993) found periportal vacuolation of the liver which apparently did not affect hepatic function, as demonstrated by the activities of liver enzymes. However, the amino acid pattern and ratios in these dogs were distorted. Grimble et al. (1969) found that in protein-deficient rats the amino acid pattern and ratios were distorted before fatty change in the liver occurred.

Ononogbu \& Emole (1978) also found swelling and vacuolation in the kidney of rats on the gari diet. Kamalu (1993) found swelling, vacuolation and rupture of the epithelial cells of the proximal convoluted tubules of the kidney of the gari-fed dogs, resulting in nephrosis. Cloudy swelling and vacuolation of such epithelial cells is a common finding in kwashiorkor (Alleyne et al. 1977). Swelling and vacuolation were also found in the pancreas (unpublished data), adrenal cortex and myocardium. In the pancreas and adrenal cortex the damage to the cells was so severe that damaged tissue had been replaced by fibrosis. There was no swelling or vacuolation in the liver, kidney, pancreas, adrenal gland or myocardium of the dogs fed on the rice + cyanide diet. The swelling and vacuolation (cellular oedema) observed was therefore a direct consequence of linamarin acting as a glucoside.

\section{KIDNEY FUNCTION}

Proteinuria occurred as early as the end of week 1 of the experiment, demonstrating that the kidney was already damaged and nephrosis was present. It appeared that linamarin exerted its influence on the $\mathrm{Na}^{+}-\mathrm{K}^{+}$-ATPase very early in the study. In kwashiorkor, disturbed renal tubular function is shown by aminoaciduria (Alleyne et al. 1977).

The hypocalcaemia in the dogs fed on gari was related to protein loss in the urine. Approximately $41 \%$ of plasma calcium is bound to protein, and the loss of large amounts of serum albumin in the urine results in a lowering of plasma calcium level.

\section{CIRCULATORY DISTURBANCES}

Kamalu (1993) observed that most tissues of the gari-fed dogs showed congestion and haemorrhage. Several factors appear to be related to this phenomenon. Degeneration and swelling of the myocardial fibres appeared to have affected the efficiency of the pumping 
action of the heart, resulting in generalized chronic passive congestion. This agrees with the findings of Philbrick et al. (1977), who showed that systolic blood pressure was reduced in a group of rats receiving a sublethal dose of linamarin $(94 \mathrm{mg} / \mathrm{kg}$ body weight) daily for 5 weeks. In kwashiorkor, cardiac output is decreased because of decreased muscle mass (Webb et al. 1986; Singh et al. 1989) and increased fat (Kuykendall et al. 1987). In addition, the apparent inhibition of the $\mathrm{Na}^{+}-\mathrm{K}^{+}$-ATPase may have caused swelling and rupture of the endothelial cells, making haemorrhage prominent. Sandhyamani (1991) found that when monkeys were maintained up to 5 months on a protein-deficient diet containing cassava starch as the carbohydrate source, the animals developed mucopolysaccharidosis of blood vessels and cardiomyopathic changes. These lesions were similar to those found in people of Kerala, where cassava is a staple.

\section{HYPOINSULINAEMIA}

Most studies have reported low fasting levels of plasma insulin in protein-energy malnutrition. Impaired glucose tolerance and reduced or absent insulin response to glucose have also been demonstrated by various authors in children with kwashiorkor (Whitehead \& Lunn, 1979; Crace et al. 1990) and rats (Okitolonda et al. 1987; Crace et al. 1989; Escriva et al. 1992). It is not particularly clear why children with protein-energy malnutrition should exhibit low fasting levels of insulin. Pimstone et al. (1973) have suggested that $\beta$-cell damage could be responsible for poor insulin secretion and impaired glucose tolerance in severe protein-energy malnutrition, and have linked this to the state of potassium depletion of their children, because potassium supplementation seemed to improve glucose tolerance. In studies of the isolated, perfused rat pancreas, Grodsky \& Bennet (1966) established that both potassium and calcium directly stimulated insulin release. Mondon et al. (1968) showed that these cations are required for insulin secretion in animals. Podolsky et al. (1973) found impaired glucose tolerance and reduced insulin response to glucose in seven patients with hepatic cirrhosis who were potassium depleted. Administration of potassium chloride for a period of two weeks or more increased body potassium, improved glucose tolerance and increased insulin response to glucose in these patients. These observations suggest that potassium depletion is associated with impaired glucose tolerance and reduced output of insulin. Impaired glucose tolerance and delayed insulin secretion in non-diabetic cassava consumers have been reported (Akpan \& Gingerich, 1991; Andrianasolo et al. 1991).

Kamalu (1991 $a$ ) used the gluconeogenic index proposed by Barej et al. (1981) to evaluate the insulin status of dogs, and found that gluconeogenesis from protein was highest in the group of dogs fed on the gari diet, being five and three times higher than gluconeogenesis from protein in the dogs fed on the rice (control) and rice + cyanide diets respectively. This indicated that the insulin level was lowest in the gari-fed dogs. The microscopic finding of fibrosis of the islets of Langerhans in the gari-fed dogs was similar to, and not more severe than, fibrosis of the islets of Langerhans in the pancreas of the dogs fed on rice + cyanide. This suggested that the states of potassium depletion and hypocalcaemia did play a role in reducing the insulin level in these dogs.

\section{PANCREATIC DYSFUNCTION AND ATROPHY}

Pancreatic dysfunction and atrophy are listed as characteristic features of kwashiorkor. Prost \& Belleville (1988) found decreased labelled amylase (EC 3.2.1.1) and lipase (EC 3.1.1.3) in malnourished rats, and Saunière et al. (1986) found low lipase in patients with kwashiorkor in a population where energy was provided mostly by manioc (cassava). 
Biochemical examination (Kamalu, $1991 \mathrm{a}$ ) revealed an abnormal elevation in plasma activity of pancreatic lipase, and microscopic examination revealed haemorrhage, necrosis, fibrosis and atrophy of the acinar tissue of the pancreas of the dogs fed on the gari diet. Pancreatic lipase activity in the dogs fed on the rice + cyanide diet was not elevated, but necrosis, fibrosis and atrophy of the acinar tissue of the pancreas were present. When the pancreas is damaged, amylase and lipase activities first rise and then decrease. In the garifed dogs lipase activity was high because tissue was still being actively damaged. This is shown by the presence of haemorrhage.

\section{MUSCLE WASTING}

Protein synthesis is usually depressed when insulin levels are abnormally low. Ibebunjo et al. (1992) found that subcutaneous fat on the carcass of gari-fed dogs was visually observed to be much greater than in the dogs fed on rice (control) and rice + cyanide. Comparison of the muscle mass index ( $\mathrm{g}$ muscle $/ \mathrm{kg}$ body weight) revealed that the pectineus and cranial tibial muscles of the hindleg in the gari-fed dogs were significantly smaller, while the biceps brachii and common digital extensor muscles of the foreleg were smaller but not significantly so, than the same muscles in the rice-fed dogs. Also the biceps brachii, common digital extensor and pectineus muscles were significantly smaller, and the cranial tibial was smaller but not significantly so, than the same muscles of the dogs fed on rice + cyanide. Whether statistically significant or not, all the muscles of the gari-fed dogs were smaller than the same muscles in the dogs of the other groups. The amount of subcutaneous fat and the muscle mass indices appeared to be related to the concentrations of insulin and the amount of gluconeogenesis in the dogs fed on rice, rice + cyanide and gari. This finding agrees with that of Koskelo et al. (1990), who studied skeletal muscle wasting, using an ultrasound method, in children with newly diagnosed acute leukaemia, and found that muscle wasting was accompanied by a simultaneous increase in adipose tissue.

\section{HYPOTHESIS}

Evidence is accumulating that free radical formation may underlie a number of pathologic processes (Robbins \& Cotran, 1979). Linamarin reduces the activity of $\mathrm{Na}^{+}-\mathrm{K}^{+}$-ATPase (Hill, 1977), resulting in electrolyte imbalance. The mechanism involved may also cause the production of free radicals in the process, amounts large enough to overcome normal protective mechanisms. This would agree with the suggestion that kwashiorkor results from an imbalance in the patient between the production of free radicals and their disposal (Golden, 1988). The hypothesis that in Nigeria, Liberia and South Africa aflatoxins have a causal role in the pathogenesis of kwashiorkor (Hendrickse, 1984) does not appear to be valid, since in the same report the author found aflatoxin in the serum of only 10 of 21 children with kwashiorkor and in 11 of 35 normally nourished children in Zimbabwe. The presence of aflatoxin, therefore, appears to be an incidental finding.

The author is proposing that intact linamarin absorbed from cassava diets, acting as a glucoside, causes inhibition of $\mathrm{Na}^{+}-\mathrm{K}^{+}$-ATPase, giving rise to electrolyte imbalance with potassium depletion. Potassium depletion causes cellular swelling (oedema), vacuolation and rupture in tissues, but at rates that differ from tissue to tissue. Swelling, vacuolation and rupture of the epithelial cells of the proximal convoluted tubules constitute nephrosis, which results in proteinuria and causes low serum albumin. Distortion of plasma amino acid pattern and ratios is related to cellular damage in the liver and pancreas and to gluconeogenesis. These characteristics - potassium depletion, oedema, nephrosis, low 
serum albumin concentration, distorted plasma amino acid pattern and ratios, increase in subcutaneous fat with muscle wasting, low insulin levels and pancreatic dysfunction and atrophy - are also characteristic features of kwashiorkor. It appears, therefore, that a direct link, intact linamarin, exists between kwashiorkor and cassava consumption. Such a linkage between cassava consumption and kwashiorkor is supported both by geographical distribution and by animal studies. The effect of intact linamarin seems to be exacerbated by low protein levels.

I wish to acknowledge the helpful comments of Professor Gaius Igboeli, University of Nigeria, Nsukka.

\section{REFERENCES}

Akpan. J. O. \& Gingerich, R. L. (1991). Association of hyperglycemia with dietary cyanogen and socioeconomic level. The study of rural communities in South-east Nigeria. Acta Diabetologica Latina 28, 29- 37.

Alleyne, G. A. O., Hay, R. W., Picou, D. I., Stanfield, J. P. \& Whitehead, R. G. (1977). Protein-energy Malnutrition. London: Edward Arnold.

Andrianasolo, H., Fleury-Goyon, M. C., Charrie, A., Andriantsoa, J., Latour, P. \& Rajaona, H. (1991). [Insulin secretion in non-diabetic cassava consumers.] Diabète et Métabolisme 17, 399-403.

Anon. (1987). Dossier. Roots and tubers: their role in food security. Courier No. 101, 62.94.

Autret, M. \& Bchar, M. (1954). Sindrome policarencial infantil (Kwashiorkor) and its prevention in Central America. (FAO Nutritional Studies No. 13). Rome: Food and Agriculture Organization.

Bailey, K. V. (1961). Rural nutrition studies in Indonesia. 2. Clinical studies of hunger oedema in the cassava areas of Java. Tropical and Geographical Medicine 13, 234-254.

Baker, D. H. \& Speer, V. C. (1983). Protein-amino nutrition of nonruminant animals with emphasis on the pig: past, present and future. Journal of Animal Science 57 (Suppl. 2), 284299.

Barej, W., Ostaszewski, P. \& Szczygiel, M. (1981). Could the plasma amino acid concentrations indicate the body protein turnover in sheep? VIth International Symposium on Amino Acid Metabolisn, Serock, Poland, pp. 214-223.

Barnard, E. A. (1969). Biological function of pancreatic ribonuclease. Nature 221. 340-344.

Barrett, M. D., Hill, D. C., Alexander, J. C. \& Zitnak, A. (1977). Fate of orally dosed linamarin in the rat. Canadian Journal of Physiology and Pharmacology 55, 134-136.

Barry, T. N., Duncan, S. J., Sadler, W. A., Millar, K. R. \& Sheppard, A. D. (1983). Iodine metabolism and thyroid hormone relationships in growing sheep fed on kale (Brassica oleracea) and ryegrass (Lolium perenne) - clover (Trifolium repens) fresh-forage diets. British Journal of Nutrition 49, 241 -253.

Boccas, B. (1987). Cassava, staple food crop of prime importance in the tropics. Courier No. 101, 72-73

Brock, J. F. \& Autret, M. (1952). Kwashiorkor in Africa (World Health Organization Monograph Series No. 8). Geneva: World Health Organization.

Chin, S. E., Shepherd, R. W., Thomas, B. J., Cleghorn, G. J., Patrick, M. K., Wilcox, J. A., Ong, T. H., Lynch, S. V. \& Strong, R. (1992). The nature of malnutrition in children with end-stage liver disease awaiting orthotopic liver transplantation. American Journal of Clinical Nutrition 56, 164168.

Cooke, R. \& Cock, J. (1989). Cassava crops up again. New Scientist 122 (1669), 63-68.

Crace, C. J., Swenne, I.. Kohn, P. G., Strain, A. J. \& Milner, R. D. G. (1990). Protein-energy malnutrition induces changes in insulin sensitivity. Diabète et Métabolisme 16, 484491

Crace, C. J., Swenne, I. \& Milner, R. D. G. (1989). Long-term follow-up after early protein-calorie malnutrition in young rats: sex difference in glucose tolerance and serum insulin levels. Metabolism 38, 933.938.

Delange, F., Bourdoux, P., Colinet, E., Courtois, P., Hennart, P., Lagasse, R., Mafuta, P., Seghers, P., Thilly. C., Vanderpas, J., Yunga, Y. \& Ermans, A. M. (1983). Nutritional factors involved in the goitrogenic action of cassava. In Cassava Toxicity and Thyroid: Research and Public Health Issues. Proceedings of a Workshop, Ottawa. 1982 (International Development Research Centre Monograph 207e). pp. 17-26 [F. Delange and R. Ahluwalia, editors]. Ottawa, Canada: International Development Research Centre.

Escriva, F., Kergoat, M., Bailbe, D., Pascual-Leone, A. M. \& Portha, B. (1992). Increased insulin action in the rat after protein malnutrition early in life. Diabetologia 34. 559-564.

Felig, P., Owen, O. E., Wahren, J. \& Cahill, G. F. (1969). Amino acid metabolism during prolonged starvation. Journal of Clinical Investigation 48, 584-594.

Food and Agriculture Organization (1970). Amino-acid content of foods and biological data on proteins (FAO Nutritional Studies No. 24). Rome: Food and Agriculture Organization.

Giesecke, D. (1985). Species differences relevant to nutrition and metabolism research. In Clinical Nutrition and Metabolic Research, Proceedings of the 7th Congress of European Society of Parenteral and Enteral Nutrition. Munich, 1985, pp. 311328 [G. Dietze. A. Grunert, G. Kleinberger \& G. Wolfram, editors]. Basel: Karger.

Glynn, I. M. (1964). The action of cardiac glycosides on ion movements. Pharmacological Reviews 16, 381407. 
Golden, M. (1988). The effects of malnutrition in the metabolism of children. Transactions of the Roval Society of Tropical Medicine and Hygiene 82, 3-6.

Gomez, G., Tellez, G. \& Caicedo, J. (1987). Effects of the addition of vegetable oil or animal tallow to broiler diets containing cassava root meal. Poultry Science 66, 725-731.

Grimble, R. F., Sawyer, M. B. \& Whitehead, R. G. (1969). Time relationships between the elevation of the serum amino acid ratio and changes in liver composition in malnourished rats. British Journal of Nutrition $23,879888$.

Grimble, R. F. \& Whitehead, R. G. (1969). The relationship between an elevated serum amino acid ratio and the development of other biological abnormalities in the experimentally malnourished pig. British Journal of Nutrition 23, 791-804.

Grimble, R. F. \& Whitehead, R. G. (1970a). Changes in the concentration of specific amino acids in the serum of experimentally malnourished pigs. British Journal of Nutrition 24, 557-564.

Grimble. R. F. \& Whitehead. R. G. $(1970 b)$. Fasting serum-aminoacid patterns in kwashiorkor and after administration of different levels of protein. Lancet $\mathbf{i}, 918920$.

Grodsky, G. M. \& Bennett, L. L. (1966). Cation requirements for insulin secretion in the isolated perfused pancreas. Diahetes 15, 910-913.

Hamaker, B. R., Rivera, K., Morales, E. \& Graham. G. G. (1991). Effect of dietary fiber and starch on fecal composition in preschool children consuming maize, amaranth or cassava flours. Journal of Pediatric Gastroenterology and Nutrition 13, 59. 66.

Hanson, R. W. \& Garber, A. J. (1972). Phosphoenolpyruvate carboxykinase. 1. Its role in gluconeogenesis. American Journal of Clinical Nutrition 25, 1010. 1021

Harper, H. A., Rodwell, V. W. \& Mayes, P. A. (1979). Review of Physiological Chemistry, 17th edn. Los Altos. CA : Lange Medical Publications.

Hendrickse, R. G. (1984). The influence of aflatoxins on child health in the tropics with particular reference to kwashiorkor. Transactions of the Roval Society of Tropical Medicine and Hygiene 78, 427-435.

Hill, D. C. (1977). Physiological and biochemical responses of rats given potassium cyanide or linamarin. In Cassava as Animal Feed, Proceedings of a Workshop. University of Guclph. 1977 (International Development Research Centre Monograph 095e), pp. 33-42 [B. Nestel and M. Graham, editors]. Ottawa, Canada: International Development Research Centre.

Howlett, W. P., Brubaker, G. R., Mlingi, N. \& Rosling, H. (1990). Konzo, an epidemic upper motor neuron disease studied in Tanzania. Brain 113, 223-235.

Ibebunjo, C., Kamalu, B. P. \& Ihemelandu, E. C. (1992). Comparison of the effects of cassava (Manihot esculenta Crantz) organic cyanide and inorganic cyanide on muscle and bone development in a Nigerian breed of dog. British Journal of Nutrition 68, 483.491

Kamalu, B. P. (199l a). The effect of a nutritionally-balanced cassava (Manihot esculenta $\mathrm{Crantz}$ ) diet on endocrine function using the dog as a model. 1. Pancreas. British Journal of Nutrition 65, 365-372.

Kamalu, B. P. $(1991 b)$. Digestibility of a nutritionally balanced cassava (Manihot esculenta Crantz) diet and its effect on growth in young male dogs. British Journal of Nutrition 66, 199208.

Kamalu, B. P. (1993). Pathological changes in growing dogs fed on a balanced cassava (Manihot esculenta Crantz) diet. British Journal of Nutrition 69, 921-934.

Kamalu, B. P. \& Agharanya, J. C. (1991). The effect of a nutritionally balanced cassava (Manihot esculenta Crantz) diet on endocrine function using the dog as a model. 2. Thyroid. British Journal of Nutrition 65 , 373379 .

Koskelo, E.-K., Saarinen, U. M. \& Siimes, M. A. (1990). Skeletal muscle wasting and protein-energy malnutrition in children with newly diagnosed acute leukemia. Cancer 66, 373-376.

Kuykendall, R. C.. Rowlands, B. J.. Taegtmayer, H. \& Walker, W. E. (1987). Biochemical consequences of protein depletion in the rabbit heart. Journal of Surgical Research 43, 62-67.

Maduagwu, E. N. (1989). Metabolism of linamarin in rats. Food Chemistry and Toxicology 27, 451.454.

Matsui, H. \& Schwartz. A. (1967). ATP-dependent binding of $\mathrm{H}^{3}$-digoxin to a $\mathrm{Na}^{+}-\mathrm{K}^{+}$-ATPase from cardiac muscle. Federation Proceedings 26, 398.

Millward, D. J. (1979). Protein deficiency, starvation and protein metabolism. Proceedings of the Nutrition Society 38, 7788.

Mondon. C. E., Burton, S. D., Grodsky, G. M. \& Ishida, T. (1968). Glucose tolerance and insulin response of potassium-deficient rat and isolated liver. American Journal of Physiology 215, 779-787.

Montgomery, R. D. (1980). Cyanogens. In Toxic Constituents of Plant Foodstuffs, 2nd edn, pp. 143-160 [I. E. Liener, editor]. New York: Academic Press.

Moran, E. F. (1976). Manioc deserves more recognition in tropical farming. World Crops 28, 184 -188.

Narendranathan, M., Sharma, K. N. \& Sosamma, P. I. (1989). Serum rhodanese in goitre and calcific pancreatitis of the tropics. Journal of the Association of Physicians of India 37, 648649.

Nartey, F. (1968). Studies on cassava, Manihot utilissima Pohl. 1. Cyanogenesis: the biosynthesis of linamarin and lotaustralin in etiolated seedlings. Phytochemistry 7, 1307.1312.

Nestel. B. (1973). Current utilization and future potential for cassava. In Chronic Cassava Toxicity, Proceedings of an Interdisciplinary Workshop, London, England, 1973 (International Development Research Centre Monograph 010e), pp. I1-26 [B. Nestel and R. Maclntyre. editors]. Ottawa. Canada: International Development Research Centre. 
Nicol, B. M. (1952). The nutrition of Nigerian peasants, with special reference to the effects of deficiencies of the vitamin B complex, vitamin A and animal protein. British Journal of Nutrition 6, 3455.

Nicol, B. M. \& Phillips, P. G. (1978). The utilization of proteins and amino acids in diets based on cassava (Manihot urilissima), rice or sorghum (Sorghum sativa) by young Nigerian men of low income. British Journal of Nutrition 39, 271-287.

Okitolonda, W., Brichard, S. M. \& Henquin, J. C. (1987). Repercussions of chronic protein-calorie malnutrition on glucose homeostasis in the rat. Diabetologia 30, 946951.

Ononogbu, I. C. \& Emole, I. (1978). The effect of garri on rat plasma cholesterol. Atherosclerosis $31,101104$.

Owen, O. E., Morgan, A. P., Kemp. H. G.. Sullivan, J. M., Herrera, M. G. \& Cahill. G. F. (1967). Brain metabolism during fasting. Journal of Clinical Investigation 46. 15891595

Padmaja, G. \& Panikkar, K. R. (1989). Pattern of enzyme changes in rabbits administered linamarin or potassium cyanide. Indian Journal of Experimental Biology 27, 551-555.

Philbrick. D. J., Hill, D. C. \& Alexander, J. C. (1977). Physiological and biochemical changes associated with linamarin administration to rats. Toxicology and Applied Pharmacology' 42, 539-551.

Phillips, T. P. (1983). An overview of cassava consumption and production. In Cassava Toxicity and Thiroid. Proceedings of a Workshop, Ottawa, 1982 (International Developmem Research Centre Monograph 207e), pp. 83-88 [F. Delange and R. Ahluwalia, editors]. Ottawa, Canada: International Development Research Centre.

Pimstone, B. L., Becker. D. \& Hendricks. S. (1973). In Endocrine Aspects of Malmutrition, p. 243 [L. I. Gardner and P. Amacher, editors]. Santa Ynez, CA: Kroc Foundation.

Podolsky, S., Zimmerman. H. J.. Burrows, B. A., Cardarelli, J. A. \& Pattavina, C. G. (1973). Potassium depletion in hepatic cirrhosis. A reversible cause of impaired growth hormone and insulin response to stimulation. New' England Journal of Medicine 288, 644-648.

Prost, J. \& Belleville, J. (1988). [Evidence for several storage and excretion ways for pancreatic digestive enzymes during protein malnutrition followed by refeeding.] Comptes Rendus des Séances de la Société de Biologie et de ses Filiales 182, 86.93.

Radwan, M. A. H., Partridge, G. G., Allan. S. J. \& Fordyce. R. A. (1989). Cassava root meal in diets for growing rabbits. Tropical Animal Health and Production 21, 32-36.

Robbins, S. L. \& Cotran, R. S. (1979). Pathologic Basis of Disease, 2nd edn. Philadelphia, PA: W.B. Saunders.

Rossouw. J. E. (1989). Kwashiorkor in North America. American Journal of Clinical Nutrition 49. 588592.

Sandhyamani, S. (1991). Cardiovascular effects in bonnet monkeys (Macaca radiata) of a cassava-based proteindeficient diet. Veterinary and Human Toxicology 33, 429430

Saunière, J. R., Sarles, H., Attia, Y., Lombardo, A., Yoman, T. N., Laugier, R., Manlan, K. \& Sahel, J. (1986). Exocrine pancreatic function of children from the Ivory Coast compared to French children. Effect of kwashiorkor. Digestive Diseases and Sciences 31, 481486.

Sihombing, D. T. H., Cromwell, G. L. \& Hays, V. W. (1971). Effect of added thiocyanate and iodine to cornsoybean meal diets on performance and thyroid status of pigs. Journal of Animal Science 33, 1154.

Singh, G. R., Malathi, K. E., Kasliwal, R. R., Ommar, A., Padmavati, S. \& Ramji, S. (1989). An evaluation of cardiac function in malnourished children by non-invasive methods. Indian Pediatrics 26. 875-881.

Söling. H.-D. \& Kleincke, J. (1976). Species dependent regulation of hepatic gluconeogenesis in higher animals. In Gluconeogenesis: its Regulation in Mammalian Species, pp. 369462 [R. W. Hanson and M. A. Mehlman, editors]. New York: John Wiley.

Tietz. N. W. \& Siggaard-Anderson, O. (1982). Acid-base and electrolyte balance. In Fundamentals of Clinical Chemistry [N. Tictz, editor], Philadelphia, PA: W. B. Saunders.

Tolboom, J. J. M.. Ralitapole-Maruping, A. P., Kabir, H., Molatseli, P. \& Anderson, J. (1986). Severe protein energy malnutrition in Lesotho, death and survival in hospital, clinical findings. Tropical and Geographical Medicine 38. 351358.

Turner, C. D. \& Bagnara, J. T. (1971). General Endocrinology', 5th edn. Philadelphia, PA: W. B. Saunders.

Viteri, F., Bèhar, M.. Arroyave, G. \& Scrimshaw, N. S. (1964). Clinical aspects of protein malnutrition. In Mammalian Protein Metabolism, vol. II, pp. 523568 [H. N. Munro \& J. B. Allison, editors]. New York Academic Press.

Waterlow, J. C. \& Vergara, A. (1956). Protein Malnutrition in Brazil (FAO Nutritional Studies No. 14). Rome: Food and Agriculture Organization.

Webb, J. G., Kiess, M. C. \& Chan-Yan, C. C. (1986). Malnutrition and the heart. Canadian Medical Association Journal 135, 753758.

Welt, L. G. (1970). Agents affecting volume and composition of body fluids. In The Pharmacological Basis of Therapeutics, 4th edn, pp. 773804 [L. S. Goodman and A. Gilman, editors]. New York: Macmillan.

Whitchead, R. G. \& Lunn, P. G. (1979). Endocrines in protein encrgy malnutrition. Proceedings of the Nutrition Society 38, 69-76.

Zinn, R. A. \& De Peters, E. J. (1992). Comparative feeding value of tapioca pellets for feedlot cattle. Journal of Animal Science 69, 4726-4733. 